\title{
Theoretical Perspectives on Corporate Social Responsibility Disclosure: A Critical Review
}

\author{
Mohamed A. Omran (Corresponding author) \\ Associate Professor of Accounting, College of Business Administration \\ Gulf University for Science \& Technology, Kuwait \\ Tel: +965 2530-7428, Fax: +965 2530-7030 \\ Email: omran.ma@gust.edu.kw
}

\begin{abstract}
Dineshwar Ramdhony
Lecturer in Accounting and Finance, Faculty of Law and Management

University of Mauritius

Email: d.ramdhony@uom.ac.mu
\end{abstract}

DOI: 10.5296/ijafr.v5i2.8035 URL: http://dx.doi.org/10.5296/ ijafr.v5i2.8035

\begin{abstract}
This study provides an extensive critical review of the theoretical perspectives applied on corporate social responsibility (CSR) disclosure literature. From a CSR standpoint we review and discuss, in detail, legitimacy theory, stakeholder theory, social contract theory, and signalling theory to identify the situations that suit each of these perspectives. The findings show that there is no universal theory applicable on corporate social responsibility disclosure for all situations or societies. While legitimacy theory suggests CSR disclosures are part of a process of legitimation, stakeholder theory offers an explanation of CSR accountability to stakeholders. Legitimacy theory seems to be more suitable for organizations working in developed countries, on the other hand, stakeholder theory appears to be most suitable for organizations working in developing countries; where a corporation can manage its stakeholders and the pressure to comply with existing legislation is less as compared to the developed countries. Social contract theory is appropriate for developed/emerged economies, as CSR disclosure exists due to an implicit social contract between business and society, which implies some indirect obligations of business towards society. Signalling theory will suit a situation where firms are competing for resources. A firm willing to demarcate from other firms will engage in more CSR practices. It is also important that the signal reaches the target audience by reporting on CSR.
\end{abstract}


Keywords: Corporate social responsibility, Stakeholder theory, Legitimacy theory, Philanthropic activity, Signalling theory, Social contract theory

\section{Introduction}

Research on social and environmental disclosures has flourished over the past years with reporting on corporate social responsibility (CSR) information now considered to be an important component, complementing financial reporting to reduce information asymmetry. A significant body of evidence across business research disciplines examines questions such as which types of firms engage in CSR, and how CSR shapes firm decisions and outcomes (Huang and Watson, 2015). There is an array of empirical research on CSR ranging from the effect of particular events on CSR disclosures (Mahadeo et al. 2011, Rashid, 2011; Deegan et al., 2002; Deegan et al., 2000) to the determinants of CSR disclosures (Ntim and Soobaroyen, 2013; Khan, 2010). Yet to our knowledge there is no recent, broad review of theoretical perspectives, which can be used to explain the disclosure of CSR information.

According to Deegan (2013), different researchers can study the same phenomenon using alternate theoretical perspectives. Consequently, a novice researcher is sometimes confused as to which theory to use. Additionally, there is also a lack of guidance on theories to be used for a particular study. Therefore, this paper enlightens the CSR investigators to apply the proper theory in the appropriate situation. Previous studies covered theories linked to voluntary disclosure research (Omran and El-Galfy 2014; Junior et al., 2014, Van der Laan, 2009). Research on voluntary disclosures looms large including topics such as corporate strategy, financial review, segmental information, sustainability reporting, CSR reporting, climate change, internet financial and non-financial reporting, corporate governance disclosures, to name a few. We narrow our research on theories used to explain CSR disclosures. We contend that not all theories applicable to voluntary reporting literature can be used to explain social and environmental reporting. Junior et al. (2014) assert that different types of information are directed towards different users, for instance, strategic and financial information are set for investors while non-financial information are the target of other stakeholders and investors. As a result, the theories used will depend on the type of information disclosed. Furthermore, social and environmental information is arguably non-financial in nature and cannot be explained by the same theories that focus on forward looking and financial information.

The rest of the paper is organized as follows. Section two provides a review of literature based on concepts and models of CSR. Section three discusses and reviews CSR theories, followed by findings of the study.

\section{Literature review}

\subsection{CSR concepts}

CSR has been defined in different ways through previous CSR literature. According to 


\section{Mll Macrothink}

International Journal of Accounting and Financial Reporting

ISSN 2162-3082

2015, Vol. 5, No. 2

Bowen (1953), social responsibilities refer to "the obligation of businessman to pursue those policies, to make those decisions, or to follow those lines of action that are desirable in terms of objectives and values of our society". Carroll (1979) argues that the social responsibility of business encompasses economic, legal, ethical and discretionary expectations that society has of organizations at a given point in time. This approach encompasses a whole range of responsibilities of a firm. CSR is about how firms manage business operations to produce positive impact on society. Consequently, firms need to account for the quality of their management (both in terms of people and process) and the nature of and quantity of their impact on society in various areas (Baker, 2004). An organization needs to define its role within the society and implement the necessary ethical, responsible, legal, and social standards (Lindgreen et al., 2008; Lichtenstein et al., 2004). Therefore, an organization has an obligation to consider the interests of customers, employees, shareholders, communities and ecological considerations in all aspects of their operations (Gokulsing, 2011; Gössling and Vocht, 2007).

Kotler and Lee (2005) identify six major initiatives under which most CSR related activities fall generating a positive impact on the firm. Firstly, corporations provide funds, in-kind contributions or other corporate resources to build awareness and concern for social cause or to support fundraising, participation or volunteer recruitment for a cause. Secondly, corporations commit to donating a percentage of revenues to a specific cause based on product sales. Thirdly, corporations support the development and/or implementation of a behavior change campaign intended to improve health, safety, the environment or community well-being. Fourthly, corporations directly contribute to charity or causes in the form of cash donations and/or in-kind services. Fifthly, corporations support and encourage retail partners and/or franchise members to volunteer their time to support local community organizations and causes. Finally, corporations adopt and conduct discretionary business practices that support social causes to improve community well-being and protect the environment.

\subsection{CSR models}

Carroll (1991) makes a distinction between different kinds of organizational responsibilities. This distinction is referred to as a firm's "pyramid of CSR" (see Figure 1 below).

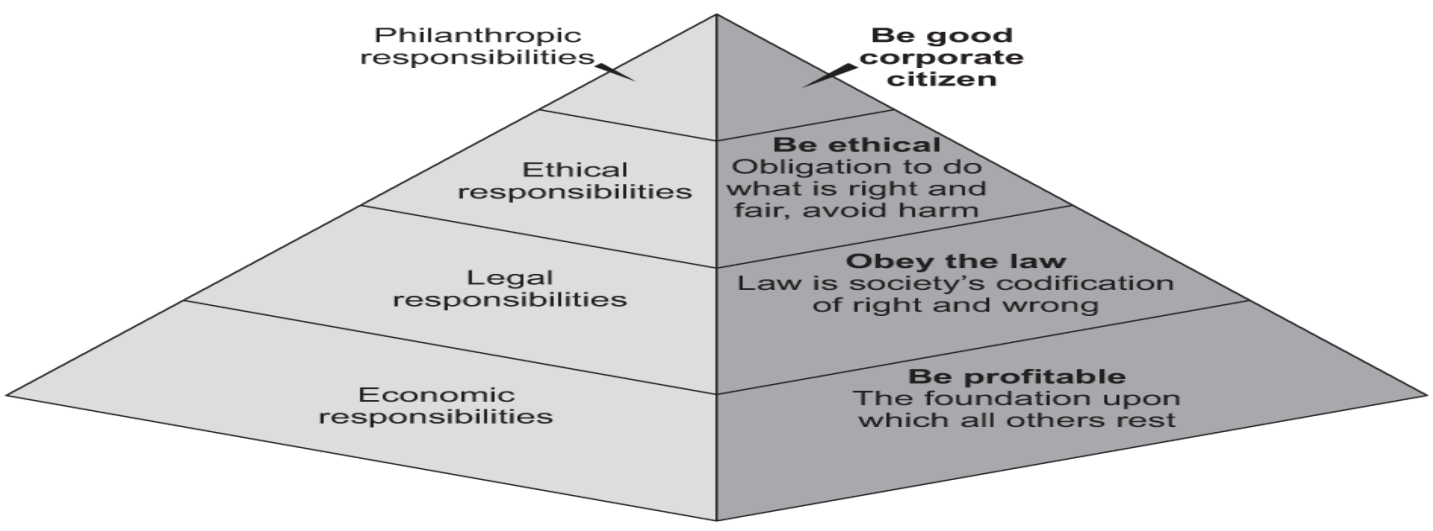

Figure 1. Carroll's (1991) CSR Pyramid

The pyramid implies a hierarchy of responsibilities moving from economic and legal through more socially oriented ones of ethical and philanthropic responsibilities. Carroll (1991) 


\section{$\triangle$ Macrothink}

International Journal of Accounting and Financial Reporting ISSN 2162-3082

argues that business institutions are basic economic units in society and have a responsibility that is economic in nature or kind. The economic responsibility is the most fundamental responsibility of a firm, which reflects the essence of a firm as a profit-making business organization. Economic responsibility implies that society expects business to produce those goods and services demanded and make a profit as an incentive or reward for the business' efficiency and effectiveness. The legal responsibilities entail expectations of legal compliance and playing by the "rules of the games". From this perspective, society expects business to fulfil its economic mission within the framework set forth by the society's legal system (Jamali et al., 2008). Crane and Matten (2007) further add that all companies attempting to be socially responsible are required to follow the law.

According to Schwartz (2011), the ethical responsibilities embody those standards, norms or expectations that reflect a concern for what consumers, employees, shareholders and the community regards as fair, just or in keeping with the respect or protection of stakeholders' moral rights. Therefore, society expects corporations to act ethically towards its stakeholders (Crane and Matten, 2007). Philanthropic responsibilities represent the smallest layer of the pyramid, involve the corporation's willingness to enhance the quality of living of their stakeholders through charitable donations and organizational support that are entirely voluntary and seen as desirable by society. The philanthropic responsibilities are sometimes on the same level as ethical. However, the difference is that it is not seen as unethical behavior if business does not contribute their money to humanitarian programs (Carroll, 1991). Schwartz and Carroll (2003) highlight certain limitations in Carroll's (1991) CSR pyramid. Firstly, the pyramid suggests a hierarchy of CSR domains whereby one may conclude that the domain at the top is more important than the domain at the base. This is clearly not the kind of CSR priorities that Carroll intended in her CSR pyramid. Secondly, the pyramid framework cannot fully capture the overlapping nature of CSR domains. Therefore, they propose an alternative approach to conceptualize CSR- a three domain model (economic, legal, and ethical responsibilities).

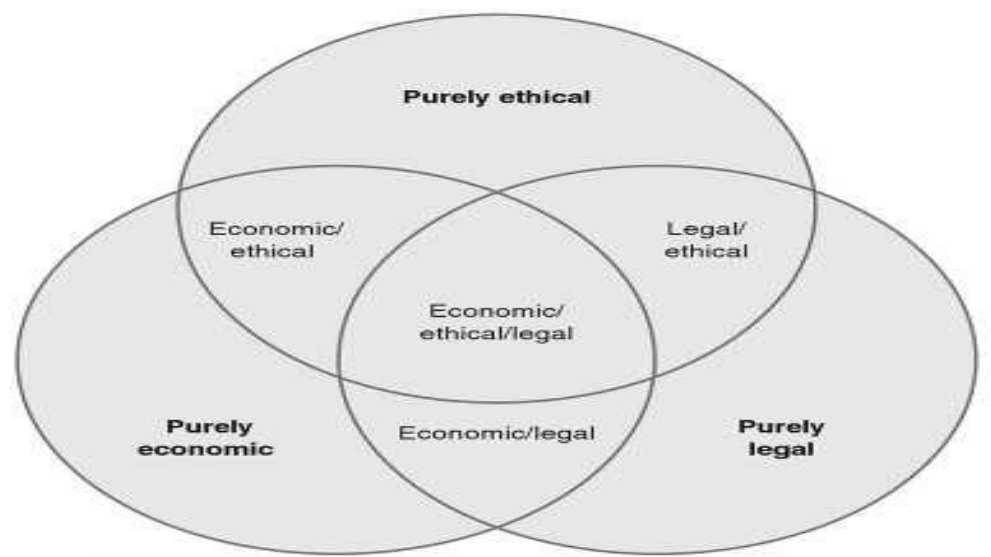

Figure2. Three domain model of CSR (Doherty et al., 2009)

The Venn model framework yields seven CSR categories from an overlap of the three core domains. However, the exception with this model is that the philanthropic category, if exist, 
is subsumed under the ethical and/or economic domains. Figure 2 illustrates the Venn model framework originated from Schwartz and Carroll (2003). In a review of CSR in developing countries,

Visser (2006) bases himself on the empirical studies undertaken by Pinkston and Carroll (1996), Edmondson and Carroll (1999), and Burton et al. (2000) to underline the fact that culture may have an important influence on perceived CSR priorities. As such, the widely accepted Carroll's (1991) pyramid is revisited in the context of developing countries as shown in Figure 3.

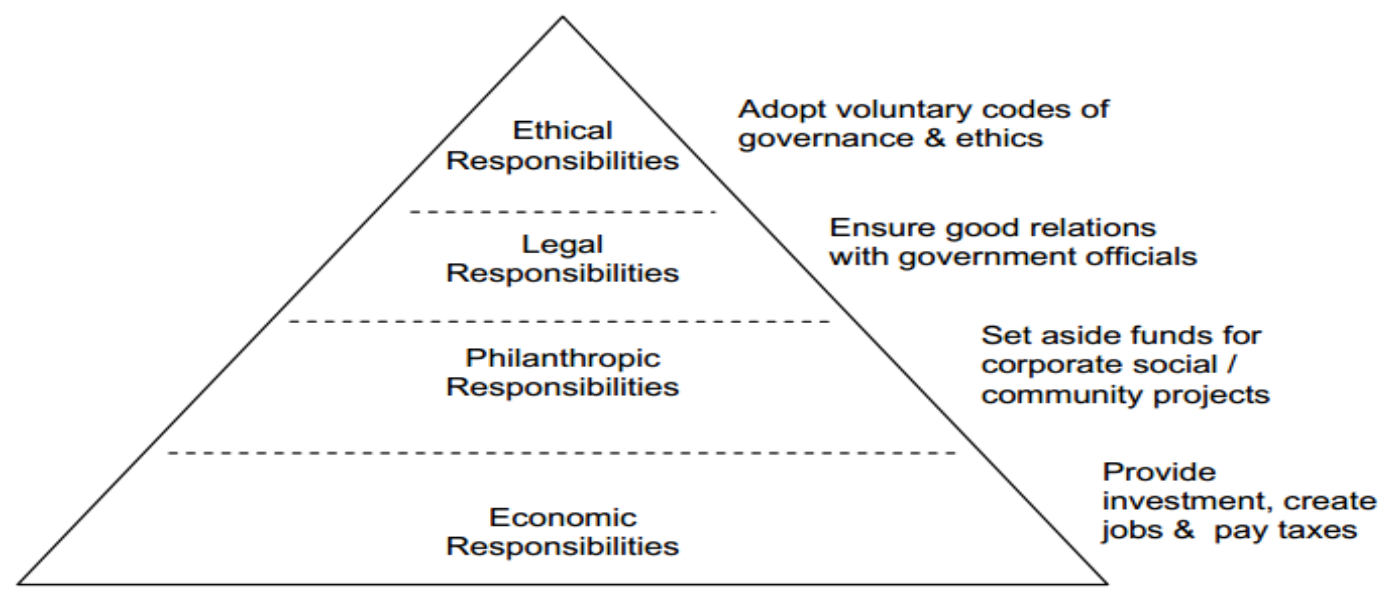

Figure 3. CSR pyramid in developing countries (Visser, 2006)

Visser (2006) contends that the order of CSR layers in developing countries differs from Carroll's (1991) classic pyramid. In developing countries, even if economic responsibilities still get the most emphasis, philanthropy is given the second highest priority followed by legal and ethical responsibilities. This is explained partly by the traditional attachment to philanthropy by the fact that it is most direct way to improve living conditions in their immediate surroundings and also by a traditional culture of fatalism, dependence and assistance in developing countries. Conversely, the pressure to comply with existing legislation is less as compared to the developed countries (Ragodoo, 2009).

\section{CSR disclosure theories}

Holder-Webb et al. (2009) assert that "it is not enough for corporations to simply engage in CSR activities but it is also important and desirable to make information about these activities available to stakeholders". Additionally, the call for disclosure of non-financial information has grown in response to the awareness that financial statement omits salient information about the firm (Adams et al., 2011; Adams, 2002). The financial statement actually portrays a limited picture of the firm through providing merely financial metrics. Therefore, the relevance of non-financial information has increased significantly over the years. The emergence of non-financial reporting can be seen as an attempt to increase transparency with respect to corporate actions concerning social and environmental issues (Nielsen and Thomsen, 2007). Further, it is acknowledged that the disclosure of non-financial information 


\section{Mll Macrothink}

International Journal of Accounting and Financial Reporting

ISSN 2162-3082

2015, Vol. 5, No. 2

is essential to reduce information asymmetry that exists between management and key stakeholders as well as to allow investors to better assess key areas of performance and support a broader view of corporate performance that encompasses society at large (Huang and Watson, 2015). Along with the increased interest to engage in CSR activities, today, corporations across the world are more voluntarily disclosing information about their CSR performance. Unquestionably, numerous motivational bases can explain companies' involvement in CSR reporting practices (Holder-Webb et al., 2009).

As CSR, the voluntary commitment for non-economic goals going beyond legal requirements, comes more and more to the center of public and academic debates (Schmitz and Schrader, 2015), therefore, we provide a comprehensive and analytical review of the theoretical perspectives on corporate social responsibility disclosure. Further, we discuss the context in which the theories used to explain the CSR disclosure practices including legitimacy theory, stakeholder theory, social contract theory, and signalling theory are more appropriate.

\section{Legitimacy theory}

Deegan and Unerman (2011) assert that the legitimacy theory relies upon the notion that there is a "social contract" between an organization and the society in which it operates. Therefore, corporation try to legitimize their corporate actions by engaging in CSR reporting to get the approval from society (societal approach) and thus, ensuring their continuing existence. The social contract as explained by Deegan (2002), represents myriad of expectations that society has about how an organization should conduct its operations. O'Donovan (2002) argues that the legitimacy theory stems from the idea that for corporations to continue operating successfully, it must act within the bounds and norms of what society identifies as socially responsible behavior. Maignan and Ralston (2002) provide that legitimacy of a firm is dependent on the maintenance of reciprocal relationship with its stakeholders, given that the firm has obligations including moral obligations to a broad range of stakeholders in to their shareholders (Adams et al., 1998).

According to Kytle et al. (2005), CSR reporting practices have become a key management tool to the growing complexity to multinational business management. They further argue that CSR reporting helps to integrate CSR activities into companies' strategic risk management so that the impact of CSR activities can be maximized. Waddock et al. (2002) argue that employee's perceptions about how a corporation accepts and manages its responsibilities are often part of the employee's decision about where to work. Therefore, publication of sustainability related information can play a role of positioning a firm as an 'employer of choice' and as such, this status can enhance loyalty, reduce staff turnover and increase a firm's ability to attract and retain high quality employees. Margolis and Walsh (2003) claim that corporation's engagement in CSR activities and its disclosure can foster corporate performance and as such their research conclude a positive relationship between CSR performance and financial performance (shareholder approach). Roberts (1992) asserts that one way that firms consider CSR disclosure is to increase access to capital and shareholder value by satisfying stakeholder's expectation. Investors are choosing to invest in organizations that are demonstrating a high level of CSR. Branco and Rodrigues (2008) argue 


\section{MInstitute Macrothink $_{\text {Int }}$}

International Journal of Accounting and Financial Reporting ISSN 2162-3082 2015, Vol. 5, No. 2

that CSR disclosures play an important mechanism to enhance the effect of CSR on corporate reputation as well as representing a signal of improved social and environmental conduct. Bayoud et al. (2012) confirm that a high level of CSR disclosures is strongly associated with corporate reputation for stakeholder group (stakeholder approach).

\section{Stakeholder theory}

Consistent with stakeholder approach, organizations are not only accountable to their shareholders but should also consider the contrasting interest of all other stakeholders that can affect or be affected by the achievement of organization's objective (Freeman, 1984). The stakeholder theory is used to analyze those groups to whom a firm should be responsible. Boatright (2003) affirms that corporations are operated or ought to be operated for the benefit of all those who have a stake in the firm. Hence, like shareholders invest their money in enterprises, employees invest their time and intellectual capital, customers invest their trust and repeated business and communities provide infrastructure and education for future employees (Graves et al., 2001).

The stakeholder theory embraces that business organizations must play an active role in society in which they operate. Consequently, Wicks et al. (2004) assert that corporations should consider the effect of their actions upon stakeholders who have an interest or "stake" in the corporations. Wearing (2005) provides that stakeholder theory stresses the importance of all parties, who are affected, either directly or indirectly, by a firm's operation. The stakeholder theory can also be explained using managerial and ethical branches (Deegan, 2013). The managerial branch posits that organizations will respond to those stakeholders who can have necessary economic impact upon the organization (O'Dwyer, 2003) or those who are not directly engaged in the organization's economic activities but have an interest in the actions of the organization and can influence it (Savage et al., 1991). On the other hand, the ethical branch simply provides that all stakeholders have a right to know about social and environmental implications of an organization's operations at all times (Deegan, 2013).

\section{Social contract theory}

Social contract thinking has its historical precedence in Hobbes (1946), Rousseau (1968), and Locke (1986). Donaldson (1982) views the business and society relationship from the philosophical thought. He argues that there exist an implicit social contract between business and society and this contract implies some indirect obligations of business towards society. Social contract thinking is explicitly recognized as a form of post conventional moral reasoning (Rest, 1999). The social contract theory is further extended by Donaldson and Dunfee et al. (1999) who in turn propose an integrative social contract theory as a way for managers to take decision in an ethical manner. According to the societal approach, firms are responsible to society as a whole, of which they are an integral part. The main idea behind this view is that business organizations operate by public consent in order to serve constructively the needs of society to the satisfaction of society (Van Marrewijk, 2003). The societal approach appears to be a strategic response to changing circumstances and new corporate challenges previously not occurred such as CSR. 


\section{MInstitute Macrothink $_{\text {Int }}^{\text {Intis }}$}

International Journal of Accounting and Financial Reporting ISSN 2162-3082 2015, Vol. 5, No. 2

Ramanthan (1976) proposes to define the concepts of social components, social equity, and net social contribution. Social components are different of social groups to which the company is supposed to be bound by a social contract. Each of these groups can measure changes in its rights with respect to the company, resulting from social transactions: thus, he defines social equity. Finally, it is possible to define the net social contribution of a firm as the aggregation of its non-market contributions to the welfare of the Society, less non-market withdrawals made by the firm on the resources of the society (Toukabi et al., 2014). As Dunfee (2006), social contact theory will suit an emerged economy where individuals are able to direct scarce resources to their highest valued use, where government is limited to its efficient ends, where free-moving prices are allowed to signal the relative value of alternate uses for scarce resources without the distortion of taxes, where the value of money is predictable, and where private property rights and contracts between individual decision makers are enforced in an unbiased fashion (Rest, 1999).

\section{Signalling theory}

Signalling theory explains why firms have an incentive to report information voluntarily to the capital market: voluntary disclosure is necessary in order for firms to compete successfully in the market for risk capital. Insiders know more about a company and its future prospects than investors do; therefore, investors will protect themselves by offering a lower price for the company (Omran and El-Galfy, 2014; Thorne et al., 2014). However, the value of the company can be increased if the firm voluntarily reports (signals) private information about itself (i.e., CSR) that is credible and reduces outsider uncertainty (Connelly et al., 2011; Mahoney, 2012).

Although the signalling theory was originally developed to clarify the information asymmetry in the labor market (Spence, 1973), it has been used to explain voluntary disclosure in corporate reporting (Ross, 1977). As a result of the information asymmetry problem, companies signal certain CSR information to investors to show that they are better than other companies in the market for the purpose of attracting investments and enhancing a favorable reputation (Verrecchia, 1983). CSR disclosure is one of the signaling means, where companies would disclose more CSR information than the mandatory ones required by laws and regulations in order to signal that they are better (Mahoney, 2012; Thorne et al., 2014). Toms (2002) suggests that implementation, monitoring, and disclosure of environmental policies and their disclosure in annual reports contribute significantly to the creation of environmental reputation as prior financial performance has no impact and there is no evidence that environmental reputation is created by a financial halo effect or by the availability of slack financial resources. Hasseldine et al. (2005) integrate quality-signalling theory and the resource based view of the firm to test the differential effects of the quantity and quality of environmental disclosures on the firm's environmental reputation. Thorne et al. (2014)_suggest that quality of CSR disclosure rather than mere quantity has a stronger effect on the creation of environmental reputation amongst executive and investor stakeholder groups. Connelly et al. (2011) provide a concise synthesis of the signalling theory and its key concepts; review its use in the management literature, and put forward directions for future research that will encourage scholars to use signalling theory in new ways and to develop 
more complex formulations and nuanced variations of the theory (Mahoney, 2012).

\section{Findings}

While legitimacy theory looks at society as a whole, the stakeholder theory recognizes some selective groups within the society to be more powerful than others. Specialty fields like CSR accounting, intellectual capital, and environmental disclosure studies fit well into the legitimacy theory and stakeholder's theory (Sharma, 2013). Although these two theories are considered complementary rather than competing theories, their use will depend on the identified user group for CSR disclosures. Legitimacy is obtained from the society as a whole rather than investors (Junior et al., 2014). Legitimacy based CSR studies will suit situations where firms have been previously accused of malpractices which have affected the society as a whole. Studies by Patten (1995) and Deegan and Rankin (1996), investigating firms that have successfully been prosecuted by environment protection authorities, are concrete examples. Studies carried in countries which are multi ethnic/religious where inequality of income and opportunities prevail among different components of the society also suit the legitimacy theory (for example, see Mahadeo et al., 2011 in the Mauritian context; Van der Laan, 2009 in Australia; Abd Rahman et al., 2011 in Malaysia). Since the legitimacy theory is based on the society's perception, management is forced to disclose information that would change the external users' opinion about their company (Cormier et al., 2004; Linthicum et al., 2010). According to Omran and El-Galfy (2014), the legitimacy theory is mostly suitable for corporations working in developed countries; where the annual report is seen as the major way such corporations communicate CSR information with the society as a whole (Adams et al., 1998).

On the other hand, the stakeholder theory seems to be most suitable for multinational corporations working in developing countries. The company can target its CSR disclosures towards those stakeholders it wants to manage to achieve the desired relationship with those stakeholders (Bushman and Landsman, 2010). A majority of CSR studies carried in Bangladesh (Islam and Deegan, 2008; Belal and Owen, 2007; Rashid, 2015) adopt the stakeholder approach due to the existence of powerful buyers (stakeholders) from Western countries.

Whilst legitimacy theory and stakeholder theory may 'compete' to explain managerial motivation for CSR disclosures, they may both plausibly explain the phenomenon. However, by identifying the two quite distinct styles of corporate social disclosure, voluntary or solicited, the theoretical perspectives offered and commonly critiqued may provide better explanatory power if they were tailored to the type of corporate social disclosure (Van der Laan (2009). According to Schmitz and Schrader (2015), in a system, where all interest of society groups are already protected by law, it may be observed that recognizable private investments in CSR are lower than in other systems where this may not be the case. This could tendentiously be relevant for non-Anglo-American corporate governance systems with high legal standards in social and environmental areas like Germany, France or Japan (Hall and Soskice, 2001).

According to social contract theory, CSR disclosure exists due to an implicit social contract 


\section{Macrothink}

International Journal of Accounting and Financial Reporting

ISSN 2162-3082

2015, Vol. 5, No. 2

between business and society and this contract implies some indirect obligations of business towards society. According to the societal approach, firms are responsible to society as a whole, of which they are an integral part. Therefore, business organizations operate by public consent in order to serve constructively the needs of society to the satisfaction of society. The societal approach appears to be a strategic response to changing circumstances and new corporate challenges previously not occurred such as CSR activities and disclosures.

Social contact theory is mostly suitable for organizations working in developed economy/countries; where private property rights and contracts between individual decision makers are enforced in an unbiased fashion, where individuals may trade with others across the street, the state, or in other countries, and where government does not create frictions between economic players in the market place for ideas, goods, and services it is not surprising that the productive capacity of the market would be enhanced (Dunfee, 2006).

It is probable that there is no single motivation for making social disclosure. Whether there is an economic motivation for the disclosure including a reaction to user's needs or a political motivation, it is probably a consequence of each management's particular perception of the world it faces (Freedman and Stagliano, 1992). Initially, the signalling theory was developed to clarify the information asymmetry in the labor market (Spence, 1973). Moreover, it has been used to explain voluntary disclosure in corporate reporting. Firms signal certain information to investors to show that they are better than other firms in the market for the purpose of attracting investments and enhancing a favorable reputation (Verrecchia, 1983). CSR is one of the signaling means, where firms would disclose more information than the mandatory ones required by laws and regulations in order to signal that they are superior (Campbell et al., 2001). The signalling theory is better suited to a situation where firms are competing for resources (Thorne et al., 2014). A firm willing to differentiate from other firms will engage in CSR practices that cannot be easily replicated by others (Connelly et al., 2011; Mahoney, 2012). It is also important that the signal reaches the target audience by reporting on CSR.

\section{Acknowledgement}

The authors would like to thank Mrs Vidisha Ramlugun, Lecturer of Accounting University of Mauritius for her valuable contributions that improve the quality of this paper. 


\section{Macrothink}

International Journal of Accounting and Financial Reporting

ISSN 2162-3082 2015, Vol. 5, No. 2

\section{References}

Abd Rahman, N.W.H., Zain, M.M., Hanim, N., and Al-Haj, Y.Y., 2011. CSR disclosures and its determinants: evidence from Malaysian government link companies. Social Responsibility Journal, 7(2), $181-201$.

Adams, C. A., Hill, W. Y., and Roberts, C. B., 1998. Corporate Social Reporting Practices in Western Europe: Legitimating Corporate Behaviour. The British Accounting Review, 30(1), 1 $-21$.

Adams, C., 2002. Internal organisational factors influencing corporate social and ethical reporting. Accounting, Auditing \& Accountability Journal, 15 (2), 223-250.

Baker, M., 2004. Corporate social responsibility -What does it mean? Available at: http://www.mallenbaker.net/csr/definition.phpv

Baron, D., 2008. Managerial contracting and corporate social responsibility. Journal of Public Economics, 92, 262-288.

Belal, A. R., and Owen, D. L., 2007. The views of corporate managers on the current state of, and future prospects for, social reporting in Bangladesh. Accounting, Auditing \& Accountability Journal, 20 (3), 472-494.

Boatright, R., 2003. Ethics and the conduct of business. Pearson Education International, New York.

Bayoud N. S., Kavanagh M., and Slaughter G., 2012. Factors influencing levels of corporate social responsibility disclosure by Libyan firms: A mixed study. International Journal of Economics and Finance, 4, 13-29.

Bowen, H.R, 1953.Social responsibilities of the businessman, Harper \& Row, New York.

Branco, M.C., and Rodrigues, L.L., 2008. Factors influencing social responsibility disclosure by Portuguese companies. Journal of Business Ethics, 83(4), 685-701.

Burton, B. K., Farh, J.L., and Hegarty, W.H., 2000. A cross-cultural comparison of corporate social responsibility orientation: Hong Kong vs. United States students. Teaching Business Ethics, 4(2), 151-167.

Bushman, R.M., and Landsman, W.R., 2010. The pros and cons of regulating corporate 


\section{Macrothink}

International Journal of Accounting and Financial Reporting

ISSN 2162-3082 2015, Vol. 5, No. 2

reporting: a critical review of the arguments. Accounting and Business Research, 40(3), 259-273.

Campbell, D., Shrives, P., and Saager, H. B., 2001. Voluntary disclosure of mission statements in corporate annual reports: Signalling what and to whom? Business and Society Review, 106(1), 65-87.

Carroll, A.B., 1979. A three dimensional conceptual model of corporate performance. Academy of Management Review, 4(4), 497-505.

Carroll, A.B., 1991. The pyramid of corporate social responsibility: Toward the moral management of organizational stakeholders. Business Horizons, 39-48.

Connelly, B. L., Certo, S. T., Ireland, R. D., and Reutzel, C. R., 2011. Signalling theory: A review and assessment. Journal of Management, 37(1), $39-67$.

Cormier, D., Gordon, I. M., and Magnan, M., 2004. Corporate environmental disclosure: contrasting management's perceptions with reality. Journal of Business Ethics, 49(2), 143-165.

Crane, A., and Matten, D., 2007. Business ethics, 2nd edition, Oxford University Press Inc., New York.

Deegan, C., 2013. Financial accounting theory, 4th edition, McGraw Hill Book Company, Sydney.

Deegan, C., 2002. The legitimising effect of social and environmental disclosures- a theoretical foundation. Accounting, Auditing and Accountability Journal, 15(3), 282-311.

Deegan, C., and Unerman, J., 2011. Finanical accounting theory, McGraw-Hill, Sydney.

Deegan, C., Rankin, M., and Tobin, J., 2002. An examination of the corporate social and environmental disclosures of BHP from 1983-1997. A test of legitimacy theory. Accounting, Auditing \& Accountability Journal, 15(3), 312-343.

Deegan, C., Rankin, M., and Voght, P., 2000. Firms' disclosure reactions to major social incidents: Australian evidence. Accounting Forum, 24(1), 101-130.

Deegan, C., and Rankin, M., 1996. Do Australian companies report environmental news 


\section{Ml Macrothink}

International Journal of Accounting and Financial Reporting ISSN 2162-3082

objectively?: An analysis of environmental disclosures by firms prosecuted successfully by the Environmental Protection Authority. Accounting, Auditing \& Accountability Journal, 9(2), $50-67$.

Donaldson, T., 1982. Corporations and mortality. Prentice Hill, Englewood Cliffs, New Jersey.

Donaldson, T., and Dunfee, T.W., 1999. Ties that bind: A social contracts approach to business ethics. Harvard Business School Press, Boston.

Dunfee, T., 2006. A critical perspective of integrative social contracts theory: Recurring criticisms and next generation research topics. Journal of Business Ethics, 68, 303-328.

Edmondson, V. C., and Carroll, A. B., 1999. Giving back: An examination of the philanthropic motivations, orientations and activities of Large Black-owned businesses. Journal of Business Ethics, 19(2), 171-179.

Freedman, M., and Stagliano, M.J., .1992. European unification, accounting harmonisation, and social disclosure. The International Journal of Accounting, 27(2), 112-22.

Freeman, R. E., 1984. Strategic Management: A Stakeholder Approach. Pitman, Boston.

Gokulsing, R.D., 2011. CSR matters in the development of Mauritius. Social Responsibility Journal, 7(2), 218-233.

Gössling, T., and Vocht, C., 2007. Social role conceptions and CSR policy success. Journal of Business Ethics, 74, 363-372.

Graves, S.P., Waddock, S., and Kelly, M., 2001. How do you measure corporate citizenship? Business Ethics, 12(2), 155-187.

Hall, P.A., and Soskice, H., 2001. Varieties of capitalism: The institutional foundations of comparative advantage. Oxford University Press, Oxford.

Hasseldine, J., Salama, A. and Toms, J., 2005. Quantity versus quality: the impact of environmental disclosures on the reputation of UK Plcs. The British Accounting Review, 37 (2), 153-164.

Hobbes, T., 1946. Leviathan. Blackwell, Oxford. 
Holder-Webb, L., Cohen, J., Nath, L., and Wood, D., 2009. The supply of corporate social responsibility disclosures among U.S. firms. Journal of Business Ethics, 84(4), 497-527.

Huang, X.B., and Watson, L., 2015. Corporate social responsibility research in accounting. Journal of Accounting Literature, 34, 1-16.

Islam, M. A., and Deegan, C., 2008. Motivations for an organisation within a developing country to report social responsibility information. Accounting, Auditing \& Accountability Journal, 21 (6), 850-874.

Jamali, D., Safieddine, A.M., and Rabbath, M., 2008. Corporate Governance: An International Review, 16(5), 443-459.

Junior, R.M., Best, P.J., and Cotter, J., 2014. Sustainability reporting and assurance: A historical analysis on a world-wide phenomenon. Journal of Business Ethics, 120 (1), 1-11.

Khan, Md.H.U.Z., 2010. The effect of corporate governance elements on corporate social responsibility (CSR) reporting: Empirical evidence from private commercial banks of Bangladesh, International Journal of Law and Management, 52(2), 82 - 109.

Kotler, P., and Lee, N., 2005. Corporate social responsibility: Doing the most good for your company and your cause. Best practices from Hewlett-Packard, Ben \& Jerry's, and other leading companies. New Jersey, USA. John Wiley \& Sons.

Kytle, B., Hamilton, B.A., and Ruggie, J.G., 2005. Corporate social responsibility as risk management: A model for multinationals. Social Responsibility Initiative Working Paper. Cambridge, MA.

Lichtenstein, D. R., Drumwright, M. E., and Braig, B. M., 2004. The effects of corporate social responsibility on customer donations to corporate-supported nonprofits. Journal of Marketing, 68(4), 16-32.

Lindgreen, A., Swaen, V., and Johnston, W., 2008. Corporate social responsibility: an empirical investigation of US organizations. Journal of Business Ethics, 46 (3), 23-29.

Linthicum, C., Reitenga, A.L., and Sanchez, J.M., 2010. Social responsibility and corporate reputation: The case of the Arthur Andersen Enron audit failure. Journal of Accounting and

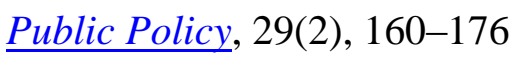


Locke, J., 1986. The second treatise on civil government: Prometheus Books.

Mahadeo, J.D., Oogarah-hanuman, V., and Soobaroyen, T., 2011. A longitudinal study of corporate social disclosures in a developing economy. Journal of Business Ethics, 104 (4), $545-558$.

Mahoney, L. S., 2012. Standalone CSR reports: A Canadian analysis. Issues in Social \& Environmental Accounting, 6(1/2), 4-25.

Maignan, I., Ralston, D.A., 2002. Corporate social responsibility in Europe and the U.S.: Insights from businesses' self-presentations. Journal of International Business Studies, 33(3), 497-514.

Margolis, J. D., and Walsh, J. P., 2003. Misery loves companies: Rethinking social initiatives by business. Administrative science quarterly, 48(2), 268-305.

Nielsen, A.E., and Thomsen, C., 2007. Reporting CSR - what and how to say it? Corporate Communications: An International Journal, 12(1), 25-40.

Ntim, C., and Soobaroyen, T., 2013. Black economic empowerment disclosures by South African listed corporations: The influence of ownership and board characteristics, $\underline{\text { Journal of }}$ Business Ethics, Springer, 116(1), 121-138.

O'Donovan, G., 2002. Environmental disclosures in the annual report: Extending the applicability and predictive power of legitimacy theory. Accounting, Auditing and Accountability Journal, 15(3), 344-371.

O'Dwyer, B., 2003. Conceptions of corporate social responsibility: The nature of managerial Capture. Accounting, Auditing and Accountability Journal, 16(4), 523-557.

Omran, M.A., and El-Galfy, A.M., 2014. Theoretical perspectives on corporate disclosure: a critical evaluation and literature survey. Asian Review of Accounting, 22(3), 257-286.

Patten, D. M., 1995. Variability in social disclosure: A legitimacy-based analysis', Advances in Public Interest Accounting, 6, 273-85.

Pinkston, T. S., and Carroll, A. B., 1996. A retrospective examination of CSR orientations: Have they changed? Journal of Business Ethics, 15(2), 199-206. 
Ragodoo, N.J.F., 2009. CSR as a tool to fight against poverty: the case of Mauritius", Social Responsibility Journal, 5(1), 19 - 33.

Ramanathan, K.V., 1976. Toward a theory for corporate social accounting. Accounting Review, 51(3), 516-529.

Rashid, A., 2011. Corporate governance in Bangladesh: a quest for the accountability or legitimacy crisis? Research in Accounting in Emerging Economies, 11(1), 1-34.

Rashid, A., 2015. The influence of stakeholder power on corporate social responsibility: Evidence from a relationship-based economy. Social Responsibility Journal, 11(2), 270 289.

Rest, J., Narvaez, D., Bebeau, M., and Thoma, S., 1999. Postconventional moral thinking: A Neo-Kohlbergian approach. Lawrence Erlbaum Associates, New Jersey.

Roberts, R. W., 1992. Determinants of corporate social responsibility disclosure: An application of stakeholder theory. Accounting, Organisations and Society, 17(6), 595- 612.

Ross, S. A., 1977. The determination of financial structure: The incentive signalling Approach, Bell Journal of Economics, 8(1), 23 - 40.

Rousseau, J., 1968. The Social Contract. Penguin, USA.

Savage, G.T., Nix, T.W., Whitehead, C.J., and Blair, J.D., 1991. Strategies for assessing and managing organizational stakeholders. Academy of Management Executive, 5(2), 61-75.

Schwartz, M.S., and Carroll, A. B., 2003. Corporate social responsibility: A three domain approach. Business Ethics Quarterly, 13(4), 503-530.

Schwartz, M.S., 2011. Corporate social responsibility: An ethical approach. Business \& Economics. Broadview Press [Online]. Available from:

http://books.google.mu/books/about/Corporate_Social_Responsibility.html?id=guf4qEFG6O 0C\&redir_esc=y [Accessed 23 November 2012].

Schmitz, J., and Schrader, J., 2015. Corporate social responsibility: a microeconomic review of the literature. Journal of Economic Surveys, 29(1), 27-45. 
Sharma, N., 2013. Theoretical framework for corporate disclosure. Research Asian Journal of Finance \& Accounting, 5(1), 183-196.

Spence, M., 1973. Job market signalling. Quarterly Journal of Economics, 87(3), 355-374.

Toms, J., 2002. Firm resources, quality signals and the determinants of corporate environmental reputation: some UK evidence. The British Accounting Review, 34(3), 257-282.

Thorne, L., Mahoney, L., Manetti, G., 2014. Motivations for issuing standalone CSR reports: A survey of Canadian firms, Accounting, Auditing and Accountability Journal, 27(4), 686 714.

Toukabri, M., Ben Jemâa, O., and Jilani, F., 2014. Corporate social disclosure: Explanatory theories and conceptual framework. International Journal of Academic Research in Management, 3(2), 208-225.

Van der Laan, S. L., 2009. The role of theory in explaining motivation for corporate social disclosures: Voluntary disclosures vs. solicited disclosures. Australasian Accounting, Business and Finance Journal, 3(4), 14-29.

Van Marrewijk, M., 2003. Concepts and definitions of CSR and corporate sustainability: Between agency and communion. Journal of Business Ethics, 44, 95-105.

Verrecchia, R. E., 1983. Discretionary disclosure. Journal of Accounting and Economics, 5(3), 179-194.

Visser, W., 2006. Revisiting Carroll's CSR pyramid: An African perspective, In Pedersen E.R., and Huniche, M. (ed.), corporate citizenship in developing countries, Copenhagen. Copenhagen Business School Press, 29-56.

Waddock, S., Bodwell, C. and Graves, S., 2002. Responsibility: The new business imperative. Academy of Management Executive, 16(2), 132-149.

Wearing, R., 2005. Cases in corporate governance. London. SAGE Publications.

Wicks, A. C., Freeman, R. E., and Parmar. B., 2004. Stakeholder theory and the corporate objective revisited. Organization Science, 15(3), 364-369. 


\section{Macrothink}

International Journal of Accounting and Financial Reporting

ISSN 2162-3082

\section{Copyright Disclaimer}

Copyright for this article is retained by the author(s), with first publication rights granted to the journal. This is an open-access article distributed under the terms and conditions of the Creative Commons Attribution license (http://creativecommons.org/licenses/by/3.0/). 